\title{
Relationship Between Biology Teachers' Level of Creativity in Teaching and Academic Performance of Secondary School Students in Awka South, Anambra State
}

\author{
Mbaegbu Chioma Stephanie ${ }^{1}$, Awosika Opeyemi Fadekemi ${ }^{1}$, Akachukwu Esther Ebele ${ }^{1}$, \\ Ikusika Bamidele Adunola ${ }^{2}$ \\ ${ }^{1}$ Department of Science Education, Nnamdi Azikiwe University, Awka, Nigeria \\ ${ }^{2}$ Department of Pure and Applied Science, Institution Federal College of Dental Technology and Therapy Enugu, Enugu, Nigeria \\ Email address: \\ cs.mbaegbu@unizik.edu.ng (M. C. Stephanie), of.aluko@unizik.edu.ng (A. O. Fadekemi), estherakachukwu18@gmail.com (A. E. Ebele), \\ sehindele@gmail.com (I. B. Adunola)
}

\section{To cite this article:}

Mbaegbu Chioma Stephanie, Awosika Opeyemi Fadekemi, Akachukwu Esther Ebele, Ikusika Bamidele Adunola. Relationship Between Biology Teachers' Level of Creativity in Teaching and Academic Performance of Secondary School Students in Awka South, Anambra State. American Journal of Biological and Environmental Statistics. Vol. 6, No. 4, 2020, pp. 71-75. doi: 10.11648/j.ajbes.20200604.12

Received: October 23, 2020; Accepted: November 11, 2020; Published: November 23, 2020

\begin{abstract}
The study assessed the relationship between biology teachers' level of creativity and academic performance of secondary school students in Anambra state. Creativity in biology education relates to the processes and particularly the personal and thinking skills that children can develop which will support deep levels of learning. It is the tendency to generate or recognize ideas, alternatives, or possibilities that may be useful. Two research questions were answered using correlation coefficient, arithmetic mean, standard deviation and one null hypothesis tested using one-way ANOVA at 0.05 level of significance. The study adopted a correlational survey design. A purposive sampling technique was used to select 77 biology teachers from 21 public schools Awka Education Zone of Anambra State, Nigeria. Biology Teachers Level of Creativity in teaching Biology (BTLCTB) was the instrument for data collection. The instrument was validated by experts and reliability was established at 0.93 using Cronbach's Alpha. Result of the findings revealed that the level of creativity of a biology teacher determines how effectively he/she teach, the ability to produce original materials, flexibility in teaching, quality of ideas and adequate elaboration in the classroom with innovative skills and strategy shows the level of creativity of a biology teacher, and biology teachers with these qualities are classified as teachers with high level of creativity. Recommendations among others is that biology teachers should be encouraged to be creative in classroom, as their level of creativity will not only make their lesson interesting, but will also motivate the students for better performance.
\end{abstract}

Keywords: Relationship, Biology, Creativity, Academic Performance

\section{Introduction}

Biology is a creative subject and teachers need to be prepared to present it in more varied ways, including being prepared to give students room to explore. In doing this teachers are not only allowing themselves access to what biology is, but also offering situations in which students can reveal their strengths and highlight areas where they need greater support. Biology is one of the core subjects at both the senior secondary school levels. The importance of biology in any medical, science and technology and industrial oriented society cannot be underestimated. The various Governments in Nigeria have continued to emphasize the role of biology in technology and scientific development of the nation.

According to previous study, the failure of the teachers to devise creative means of enriching the class is one of the reasons why the lesson of biology is ever becoming a subject of discussion among students, and consequently leads to poor performance, whenever they sit for examination that has to do with biology [6]. It is an undisputable fact that an adequate competent and practically oriented biology teachers is an essential ingredient for biology teaching [10]. Such teachers are supposed to be with substantial amount of 
knowledge that is capable of making them successful in the process of their delivery in the classroom. This was further noted by [1] that one of the characteristics of good teachers is that, they possess a substantial amount of specialized creative knowledge that nourishes pedagogical content knowledge, which they use to generate ideas for effective teaching.

The value attached to creativity in biological knowledge will justify the goals of biology teaching and learning [2] stated that in Nigeria, there are six macro goals of biology teaching and learning, they are as follows:

1. To generate interest in biology and provide a solid foundation for everyday life;

2. To develop computational skills and foster the desire and the ability to be accurate to a degree relevant to the problem at hand;

3. To develop die ability to recognize problems and to solve them with related biological knowledge;

4. To develop precise, logical and abstract thinking;

5. To provide necessary biological background for further education; and

6. To stimulate and encourage creativity.

Creative teaching for creative learning is not merely a question of presentation of subject matter content by teacher, rather it is the teaching and learning strategies that determine the potential for creative learning, which can lead to good academic performance. Creative teaching, which aims to develop pupils' own creative thinking processes, could be said to move the focus away from the teachers' delivery and towards the pupils' learning. The range of constructivist strategies suggested by [4] may encourage scientific activity, and highlight the way in which creative teaching and creative learning are interrelated, in so much as the strategies a teacher selects, will ultimately determine the opportunities children have, to become creative learners.

Creativity could be explained as the ability to transcend traditional ideas, rules, patterns, relationship, or the like and to create meaningful new ideas. It is the tendency to generate or recognize ideas, alternatives, or possibilities that may be useful. Creativity in biology education relates to the processes and particularly the personal and thinking skills that children can develop which will support deep levels of learning. It has been described by [12] as the quality of the thinking taking place - a breakthrough in thinking - a creative moment, and significant to learning which can initiate powerful and challenging learning experiences and harnesses the imaginative power of individuals. According to [5] the level of creativity of biology teachers goes a long way to determine how effective the teacher delivers the subject to the learners and the level of performance of the students. [12] stated that the biology teachers' level of creativity can be assessed on their level of originality, flexibility, fluidity, elaboration, and mastery of the subject matter.

Originality is related to the capacity of a task to act upon a person and upon the creative product. An original task provokes unexpected and intelligent responses from remote premises; it causes the student to evade a previous conceptual system and build a new one that affects both ideas and people, it brings about innovative ideas, statistically infrequent. A potentially original task should promote novelty, unpredictability and surprise. Flexibility shows the capacity of the teacher to look into a biology concept from different angles; to play with the elements of a set and to operate without being bound to rigid forms; their capacity to understand meanings in situations or irrelevant facts, their receptivity and tolerance to ambiguity; their acceptance towards conflict and tension that arise from polarity; making argumentation richer. Fluidity is the capacity to produce a big quantity of ideas, but having in mind that it is not enough to produce a big amount of ideas to be creative. The fluid task generates alternatives, approaches, solutions, combinations, association capacity, completion and production of relations. Elaboration in a task appears when the generating process is focused,' with attention to detail, carefully and meticulously. It allows the teacher to organize the content, to imagine the following steps once the images, thoughts and statements have been conceived.

Studies has shown that students' rate of failure in biology in Nigeria is very high [6]. Many researchers attributed this to the level of equality of the teachers which affect their method of teaching. It is in view of this that Ball, (2013) argued that the poor performance of students in biology in developing countries can be attributed to the level of creativity of the biology teachers and how effective they can teach in order to achieve good performance. Academic performance is the measurement of student achievement across various academic subjects. Academic performance is the extent to which a student, teacher or institution has attained their short or long-term educational goals. Completion of educational benchmarks such as secondary school diplomas and bachelor's degrees represent academic achievement [11]. The work were of the view that Academic achievement is commonly measured through examinations or continuous assessments but there is no general agreement on how it is best evaluated or which aspects are most important-procedural knowledge such as skills or declarative knowledge such as facts [3]. Hence, this study was on the relationship between biology teachers' level of creativity for effective teaching and academic performance of secondary school students in Anambra State.

The work [14] shows application of modern tools in 5G networks that will help in ascertaining this relationship faster and making the performance to be viewed at will at a greater speed.

Statement of the Problem

Over the years, students' performance in Biology in WASSCE, NECO and SSCE have been unsatisfactory (Chief Examiners' 2015-2019). This has been a cause for worry among education stakeholders, teachers, researchers, biology teachers, parents and the students themselves. Regardless of the efforts made by these education stakeholders and biology teachers, the poor performance in Biology examination remains constant over the years. Most of the studies have revealed several factors responsible for that including the kind of teaching methods used, student-teacher relationship, student 
factors (attitude, retention, self-efficacy, etc), poor teaching, and teachers' level of creativity among others which is vital for ensuring quality teaching (Kareem, 2013). All hands of researchers are on deck in uprooting the causes. It is evident that achieving quality science and technology education depends largely on the effectiveness and efficiency of the science teachers' creativity in teaching science subjects such as Biology in the secondary school. It is therefore the intent of this study to assess the relationship biology teachers' level of creativity for effective teaching and academic performance of secondary school students in Anambra State.

Purpose of the study

The purpose of this study is to assess the biology teachers' level of creativity for effective teaching and academic performance of secondary school students in Anambra State. Specifically, the study sought to determine the:

Relationship between biology teachers' level of creativity for effective teaching and academic performance of students in biology.

Biology teachers' level of creativity for effective teaching of biology in secondary schools.

Research Questions

What is the relationship between biology teachers' level of creativity for effective teaching and academic performance of students in biology?

What is the biology teachers' level of creativity for effective teaching of biology in secondary schools?

Hypothesis

There is no significant relationship between biology teachers' level of creativity for effective teaching and academic performance of students in biology.

\section{Method}

Correlation coefficient and descriptive survey research were adopted for the study. The study was conducted in Awka Education Zone of Anambra State, Nigeria. The population consisted 77 biology teachers purposively selected from 21 public schools in the study area. The instrument used for data collection was a questionnaire tagged Relationship between Biology Teachers Level of Creativity in Teaching Biology (RBBTLCTB). The instrument was validated by two experts - one in biology education and the other one in measurement and evaluation, all from Nnamdi Azikiwe University, Awka. They corrected and modified the instrument to a valid form. Also the reliability of the instrument was established at 0.93 using Cronbach's Alpha method.

The questionnaire was administered to respondents individually by the researcher at their various schools in Awka Education Zone, of Anambra State. Data collected were analyzed using correlation coefficient and mean and standard deviation to answer the research questions and one way ANOVA to test the null hypothesis at 0.05 level of significance. The response options used in the work are Very high extent (VHE), High extent (HE), moderate extent (ME), low extent (ME).

Decision Rules: A correlation coefficient higher that ranges from $0.70-0.99$ is considered highly related and weighted mean score of 3.0 and above was considered as agreed, while a weighted mean score of 2.99 and below was considered disagreed with respect to the research question.

\section{Results}

Research Question 1

What is the relationship between biology teachers' level of creativity for effective teaching and academic performance of students in biology?

Table 1. Pearson Product Moment Correlation Analysis of biology teachers' level of creativity for effective teaching as it relates to the academic performance of students in biology.

\begin{tabular}{lllll}
\hline Variables & $\mathbf{X}$ & SD & N & $\mathbf{R}^{\mathbf{2}}$ \\
\hline Teachers' level of creativity & 2.67 & 0.19 & 77 & \multirow{2}{*}{0.93} \\
Students' academic performance & 31.68 & 0.38 & 0.28 \\
\hline
\end{tabular}

Table 1 shows that the mean score and standard deviation of teachers' level of creativity are 2.67 and 0.19 while that of students' academic performance in biology are 31.68 and 0.38. Also the correlation between teachers' level of creativity and students' academic performance in biology was

0.93. The coefficient of determination $(0.28)$ also known as the predictive value means is $28 \%$.

Research Question 2

What is the biology teachers' level of creativity for effective teaching of biology in secondary school?

Table 2. Biology teachers' level of creativity for effective teaching of biology in secondary school.

\begin{tabular}{|c|c|c|c|c|c|c|c|c|}
\hline $\mathbf{S} / \mathbf{N}$ & ITEMS & VHE & HE & ME & $\mathbf{L E}$ & $\mathbf{X}$ & SD & Decision \\
\hline 1. & All teachers of biology apply creativity in teaching the subject biology & 5 & 11 & 28 & 33 & 2.71 & 1.02 & Low extent \\
\hline 2. & Knowledge of biology alone is not enough to teach biology as a subject & 31 & 26 & 15 & 5 & 3.82 & 0.73 & High extent \\
\hline 3. & The ability to produce original materials and flexibility in teaching by biology teachers & 36 & 23 & 14 & 3 & 3.50 & 0.68 & High extent \\
\hline 4. & $\begin{array}{l}\text { Biology teachers with the above qualities in item no. } 3 \text { are classified as a teacher with high level } \\
\text { of creativity }\end{array}$ & 39 & 21 & 12 & 5 & 3.66 & 0.70 & High extent \\
\hline 5. & The level of creativity of a biology teacher determines how effective he/she is in teaching. & 33 & 24 & 11 & 9 & 3.43 & 0.46 & High extent \\
\hline 6. & $\begin{array}{l}\text { Biology teachers with high level of creativity are not better than those with low level of } \\
\text { creativity in effective teaching. }\end{array}$ & 9 & 13 & 23 & 32 & 1.53 & 0.96 & Low extent \\
\hline 7. & $\begin{array}{l}\text { There is no relationship between teachers' level of creativity and academic performance of } \\
\text { students in biology. }\end{array}$ & 10 & 14 & 20 & 33 & 1.94 & 0.80 & Low extent \\
\hline
\end{tabular}




\begin{tabular}{|c|c|c|c|c|c|c|c|c|}
\hline $\mathbf{S} / \mathbf{N}$ & ITEMS & VHE & HE & ME & LE & $\mathbf{X}$ & SD & Decision \\
\hline 8. & Teaching biology without creativity in the content of what is taught does not motivate the students. & 39 & 21 & 12 & 5 & 3.88 & 0.56 & High extent \\
\hline 9. & The originality materials and flexibility in teaching. & 37 & 20 & 19 & 1 & 3.96 & 0.81 & High extent \\
\hline 10. & Effective teaching of biology does not affect the students' understanding of biology. & 9 & 13 & 23 & 32 & 1.89 & 0.92 & Low extent \\
\hline
\end{tabular}

In table 2, responses of respondents to the items numbers 2, 3, 4, 5, 8 and 9 indicates mean ratings higher than the criterion mean. While the remaining items $1,6,7$ and 10 indicates mean ratings lower than the criterion mean.

Hypothesis

There is no significant difference in the mean ratings of biology teachers' level of creativity and effective teaching of biology in secondary schools.

Table 3. Shows the mean ratings of biology teachers' level of creativity and effective teaching of biology in secondary schools.

\begin{tabular}{|c|c|c|c|c|c|c|c|}
\hline & Variations & Sum of squares & df & Mean square & f-cal & Sign. & f.crit \\
\hline \multirow{3}{*}{ Var 001} & Between Groups & 12.413 & 1 & 12.413 & 15.0802 & 0.000 & \\
\hline & Within Groups & 832.022 & 76 & .749 & & & \\
\hline & Total & 844.435 & 77 & & & & \\
\hline \multirow{3}{*}{ Var 002} & Between Groups & 1.580 & 1 & 1.580 & 6.172 & .131 & 3.85 \\
\hline & Within Groups & 749.311 & 76 & .674 & & & \\
\hline & Total & 750.891 & 77 & & & & \\
\hline \multirow{3}{*}{ Var 003} & Between Groups & 85.923 & 1 & 85.923 & 60.495 & .000 & \\
\hline & Within Groups & 1711.713 & 76 & 1.460 & & & \\
\hline & Total & 1797.636 & 77 & & & & \\
\hline \multirow{3}{*}{ Var 004} & Between Groups & 32.579 & 1 & 32.579 & 35.942 & .000 & \\
\hline & Within Groups & 997.057 & 76 & .809 & & & \\
\hline & Total & 1029.636 & 77 & & & & \\
\hline \multirow{3}{*}{ Var 005} & Between Groups & 3.239 & 1 & 3.239 & 4.852 & 0.82 & \\
\hline & Within Groups & 1531.887 & 76 & 1.386 & & & \\
\hline & Total & 1532.126 & 77 & & & & \\
\hline \multirow{3}{*}{ Var 006} & Between Groups & 1.025 & 1 & 1.025 & 4.082 & & \\
\hline & Within Groups & 1030.652 & 76 & .846 & & & \\
\hline & Total & 1031.677 & 77 & & & & \\
\hline \multirow{3}{*}{ Var 007} & Between Groups & 2.536 & 1 & 2.536 & 4.526 & .112 & \\
\hline & Within Groups & 1437.010 & 76 & 1.300 & & & \\
\hline & Total & 1439.546 & 77 & & & & \\
\hline \multirow{3}{*}{ Var 008} & Between Groups & 36.341 & 1 & 36.341 & 7.74 & .060 & \\
\hline & Within Groups & 859.106 & 76 & 774 & & & \\
\hline & Total & 895.447 & 77 & & & & \\
\hline \multirow{3}{*}{ Var 009} & Between Groups & 49.504 & 1 & 49.504 & 17.89 & .001 & 3.85 \\
\hline & Within Groups & 819.755 & 76 & .777 & & & \\
\hline & Total & 869.259 & 77 & & & & \\
\hline \multirow{3}{*}{ Var 0010} & Between Groups & 11.576 & 1 & 11.576 & .001 & & \\
\hline & Within Groups & 1035.471 & 76 & .843 & & & \\
\hline & Total & 1047.047 & 77 & & & & \\
\hline \multirow{3}{*}{ Group Mean* } & Between Groups & 43.324 & 1 & 43.324 & 4.904 & .000 & $3.85 \mathrm{gdszga}$ \\
\hline & Within Groups & 869.557 & 76 & .693 & & & \\
\hline & Total & & 77 & & & & \\
\hline
\end{tabular}

The result in Table 3 indicates that the calculated $\mathrm{F}$ value is 4.904, while the critical $\mathrm{F}$ value is 3.85 for group mean interaction. The hypothesis that predicts no significant difference is hereby rejected. There is a significant difference.

Discussion of findings

The result of the study revealed that the level of creativity of biology teacher determines how effectively he/she teaches in the classroom. The ability to produce original materials, flexibility in teaching, quality of ideas generated, and adequate elaboration in the classroom with innovative skills and strategies shows the level of creativity of a biology teacher and this in tum affects the interest and academic performance of students in biology to a better side. The result of the study gave support [1], who earlier stated that one of the characteristics of good teachers is that they possess a substantial amount of specialized creative knowledge that nourishes pedagogical content knowledge, which they use to generate ideas for effective teaching.

The result also reveals that most biology teachers do not apply creativity in teaching the subject in the classroom, now the question is what then is the position of our students' performance in biology both in the internal and external examination? Is it not a continued poor performance? There is need for us to address such situation. The implication of this study is that biology teachers level of creativity, directly or indirectly affects students interest, learning and academic performance in biology. The level of creativity of biology teachers in what is taught, enables students to understand biology concepts better and even motivates them. 


\section{Conclusion}

Creativity in the biology classroom is not just about what students do, but more importantly what the teachers does to promote students' academic performance. If teachers think creatively about the biological experiences they offer students, they can easily open up opportunities for them to be creative. Biology teachers should help students to generate or recognize ideas, alternatives or possibilities that may be useful, in order to make their teaching effective within the context of improved academic performance of students. It was also observed that there is a high relationship between teachers' level of creativity and students' academic performance in biology. This means that as teachers' level of creativity increases, students' academic performance also increases.

\section{Recommendation}

Based on the findings, the following recommendations were made:

Biology teachers should be encouraged to be creative in the classroom, as their level of creativity will only make their lesson interesting, but will also motivate the students for better academic performance.

Professional bodies like National Teachers Institute (NTI), Science Teachers Association of Nigeria (STAN) that normally organize workshops and seminars should endeavor to include teachers' creativity in their module, so that teachers should be educated more on the concept as it regards to teaching.

\section{References}

[1] Adedoyin, O. O, (2011). The impact of Teachers' in-depth pedagogical biological content knowledge on academic performance: As perceived by Botswana Senior Secondary school students. European Journal of Educational Studies, 3 (2), Pp 277.

[2] Agbarevo, M. N. (2016). The effects of teachers' behavioral characteristics on students' interests in science. Journal of Research in Education, 3 (1), pp 47-50.

[3] Annie, W., Howard, W. S., \& Mildred, M. W. (2009),
"Achievement and ability tests - Definition of the domain", Educational Measurement, 2, University Press of America, pp. 2-5, ISBN 978-0-7618-0385-0.

[4] Clements, D. H. (2015). Teaching creativity with computers. Education Psychological Review 7 (2). Retrieved $3{ }^{\text {rd }}$ March, 2014 from doi: 10.1007/BF02212491. pp 141-161.

[5] Ervynck, G. (2012). Biological creativity. In D. Tall (Ed), Advanced Biological Thinking. Dordrecht: Kluwer academic Publishers, pp. 42-53.

[6] Kajuru, Y. K. (2019). Senior secondary certificate examination (SSCE) biology failure: Challenge for counselors. A. B. U. Journal of Educational Psychology and Counselling. 1 (1). Pp. 25-31.

[7] Korau, Y. k. (2010). Pedagogical strategies for improving the teaching and learning of biology at colleges of Agriculture in Nigeria. Journal of Studies in Science and Biology Education, 1 (1) Ahmadu Bello University, Zaria.

[8] Leikin, R. (2013). Exploring biological creativity using simple solution tasks. In R. Leikin, B. Berman, \& B. Koichu (Eds). Creativity in biology and the education of gifted students. Rotterdam. The Nerthalnds: Sense Publishers, pp. 129-145.

[9] Nworgu, B. G. (2015). Educational Research: Basic Issues and Methodology $\left(2^{\text {nd }} \mathrm{ed}\right)$. Nsukka: University Trust Publishers.

[10] Odili, G. A. (2016). Biology in Nigeria Secondary School: $A$ teaching perspective. Lagos: Anachua Educational Books.

[11] Okoye, R. (2018). The relationship between young children's academic achievement and measures of intelligence". Psychology in the Schools. 32 (3): 170-177. doi: 10.1002/15206807(199507)32:3<170::aidpits2310320303>3.0.co;2-k.

[12] Talboys, M. (2013). Leadership for creativity leading edge presentation given at NCSL. Retrieved $3^{\text {rd }}$ March, 2014 from doi: 10.1007/BF02212491.

[13] Uzoagulu, A. E. (2018). Practical Guide to Writing Research Projects in Tertiary Institution. Enugu: John Jacob's Classic Publishers Ltd.

[14] Alumona Theophilus (2020) 5G Applications in heteregenous network issues and challenges. International journal of computer science and mobile computing vol 9, issue 9, September $2020 \quad$ pg 94-102 doi: 10.47760/ijcsmc.2020.v09i09.010. 